Князь, Тетяна. «Когнітивний аспект дослідження фразеологізмів української мови в медійному дискурсі». Лінгвостилістичні студї, вип. 13, 2020, с. 62-71.

Kniaz, Tetiana. "Praseologisms of the Ukrainian Language in the Media Discourse: Cognitive Aspect". Linguostylistic Studies, iss. 13, 2020, pp. 62-71.

УДК 811.161.2'373.7

https://doi.org/10.29038/2413-0923-2020-13-62-71

\title{
КОГНІТИВНИЙ АСПЕКТ ДОСЛІДЖЕННЯ ФРАЗЕОЛОГІЗМІВ УКРАЇНСЬКОЇ МОВИ В МЕДІЙНОМУ ДИСКУРСІ
}

\author{
Тетяна Князь \\ Харківський національний аграрний університет ім. В.В. Докучаєва, \\ Харків, Україна
}

У статті розглянуто когнітивні процеси сприймання явищ дійсності засобами фразеології, проаналізовано комунікативно-прагматичні особливості функціонування фразеологізмів у медійному дискурсі. Фразеологізми є засобом зберігання й організації знань про навколишній світ у свідомості суспільства. Проаналізовані фразеологізми в медійному дискурсі відображають сприймання українцями негативних ситуацій, пов'язаних із суспільно-політичною сферою в країні.

Ключові слова: внутрішня форма, когнітивний аналіз, медійний дискурс, фразеологічна одиниця.

\section{PRASEOLOGISMS OF THE UKRAINIAN LANGUAGE IN THE MEDIA DISCOURSE: COGNITIVE ASPECT}

\section{Tetiana Kniaz}

Kharkiv National Agrarian University named after V. V. Dokuchaiev, Kharkiv, Ukraine

Cognitive modeling of discourse is considered to be a field of research, the aim of which is to study the structures, representing the knowledge and ways of the discourse conceptual organization in the process of its verbalization and perception.

Phraseologisms as symbolic representatives of diverse knowledge in the human mind reflect the peculiarities of thinking, worldview in the process of communication. In this regard, it is important to study phraseological units that are used to transmit different intentions in both explicit and implicit forms in media discourse, from the standpoint of cognitive and pragmatic aspects.

The elucidation of the cognitive processes of perception of the reality phenomena by means of phraseology in media discourse, as well as the analysis of pragmatic parameters of the phraseology functioning is the purpose of this scientific research. The descriptive method, functional-pragmatic, cognitive and discourse analysis method are used in the study.

Phraseologisms are the means of storing and organizing phraseological knowledge about the world around us in the human mind of society. The analyzed phraseological units in the media discourse reflect the perception of negative situations related to the socio-political sphere in the country as a whole. There is a clear evidence of the features inherent in the

(C) Князь Т., Волинський національний університет імені Лесі Українки, 2020.

Це стаття відкритого доступу на умовах CC BY-NC 4.0 
Ukrainian people mentality, which is manifested, in particular, in the ability to reproduce and be critical about the negative manifestations of actions and deeds of people.

Phraseological units as an element of headlines, besides informative and communicative functions, have additional emotional and expressive meaning that arouses interest and attracts the readers' attention. Transformation of phraseological units realizes their pragmatic potential, which contributes to the effective impact on the recipient. The use of phraseological units in media discourse promotes the implementation of various tactics: selfpresentation, discredit of the opponent etc. The analysis of the phraseological unit usage in media discourse in the cognitive aspect allows tracing the features of the conceptual sphere of both the individual and the Ukrainian people as a whole. $(\mathrm{PhU})$.

Key words: internal form, cognitive analysis, media discourse, phraseological unit

Вступ. У фокусі уваги когнітивної лінгвістики знаходиться мова як умістище важливої інформації про соціально-політичне, економічне, культурне життя народу, що склалися впродовж розвитку суспільства. Когнітивне моделювання дискурсу розглядається як напрям дослідження, мета якого - вивчення структур репрезентації знань й способів концептуальної організації дискурсу у процесі його вербалізації й сприйняття. На нашу думку, когнітивний підхід є основою дискурсивного аналізу й дозволяє не тільки з'ясувати відмінності між різними напрямами лінгвістичного дослідження, але й об'єднати, інтегрувати різні аспекти вивчення особливостей функціонування фразеологічних одиниць (ФО) у текстах медійних видань. Мовні засоби пов'язані 3 когнітивними структурами та процесами, відповідно процес комунікації пов'язаний із мисленням.

Кожна одиниця мови, на думку О. Кубрякової, може бути вивчена 3 погляду когніції й з погляду комунікації. Це положення є основою для когнітивно-дискурсивної парадигми сучасних лінгвістичних досліджень, що встановлює тісний взаємозв'язок дискурсу й когніції. Дискурс у цілому відповідає певному простору, актуалізація якого має когнітивну (пізнавальну) природу.

Вивченню дискурсу у вигляді концептів, категорій, ментальних схем, тобто різних моделей репрезентації спілкування присвячені роботи дослідників: М. Алефіренко, М. Болдирев, Т.А. ван Дейк, В.Карасик, М. Ковшова, О. Кубрякова, Л. Цурикова. Зокрема, Л. Цурикова акцентує увагу на вивченні самих структур репрезентації знання, а також способів зберігання, обробки і вилучення знань у процесі дискурсивної діяльності (135). «Дискурс є вербалізованою мовленнєво-мисленнєвою діяльністю, що розуміється як сукупність процесу й результату, що й має як власне лінгвістичні, так і екстралінгвістичі плани» відображення інформації (Красных 200).

Ключем до розуміння будь-якої картини світу $\epsilon$ лексеми, фразеологізми як знакові репрезентанти різних знань у свідомості людини, відповідно мовні засоби не лише номінують, а й відображають 
особливості мислення, світосприйняття у процесі комунікації. У зв'язку з цим актуальне вивчення фразеологічних засобів, які використовують у процесі реалізації різних намірів як в експліцитній, так і імпліцитній формах у медійному дискурсі в когнітивному та прагматичному аспектах.

Мета дослідження. 3'ясування когнітивних процесів сприймання явищ дійсності засобами фразеології в медійному дискурсі, а також аналіз прагматичних параметрів функціонування фразеологізмів становить мету пропонованої наукової розвідки.

Матеріал і метод дослідження. Матеріалом дослідження обрано фразеологізми української мови на позначення негативних дій, учинків, що функціонують у сучасних медійних виданнях. У роботі застосовано описовий метод, у межах якого використано прийоми систематизації, спостереження, інтерпретації фразеологізмів. Когнітивний аспект у вивченні фразеології передбачає не лише характеристику певної ситуації, а найперше врахування специфіки їі сприймання, наявності необхідних культурологічних знань, що сприяють цьому. Метод дискурсивного аналізу тексту дає можливість простежити механізми взаємозв'язку між пізнанням, суспільством і мовою, специфіку дискурсивних функцій фразеологізмів у конкретному тексті.

Застосування принципів когнітивного підходу до вивчення фразеології передбачає врахування особливостей зовнішньої форми й внутрішнього змісту фразеологічних одиниць, специфіки їх функціонування, правильного й точного вживання, відповідно - адекватного розуміння. Функціонально-прагматичний аналіз передбачає вивчення стратегій i тактик впливу за допомогою фразеологічних засобів у різних актах комунікації.

Результати дослідження та дискусія. Важливе значення у вивченні когнітивних процесів у мас-медіа має концепція епізодичної ситуативної моделі відомого лінгвіста Т. А. ван Дейка, що грунтується на підкресленні фундаментальної ролі моделей в соціальному пізнанні. Згідно з цією теорією у процесі породження й розуміння дискурсу суб'єкт пізнає, створює ментальне уявлення ситуації, використовуючи свої знання, що акумулюють його попередній індивідуальний досвід, емоції, установки (Дейк 76-83). Отже, науковець уважає, що люди розуміють текст тільки в тому випадку, коли розуміють ситуацію, про яку йдеться.

На думку Б. Дарбанова, саме «моделі ситуації» необхідні нам як основа для інтерпретації тексту. Використання моделей пояснює моменти, чому ті, хто слухають (читають), прекрасно розуміють імпліцитні й неясні фрагменти текстів: у цьому випадку вони активізують відповідні фрагменти ситуаційної моделі. Тільки на основі моделей ми можемо визначити істинність або хибність тих або тих фрагментів тексту, установити їх кореферентність і виявити зв'язок на локальному й глобальному рівнях (Дарбанов 73). 
Досліджуючи основи теорії масової комунікації, В. Іванов говорить про важливість вивчення когнітивних процесів, реакцій з боку аудиторії, адже саме вони приводять до того, що аудиторія по-різному реагує на медійні послання: можлива згода, спротив, можливий також ефект бумеранга. Когнітивна теорія відгуку розглядає зв'язок між когнітивними процесами під час обробки інформації та можливими змінами установок. При цьому слід особливо враховувати ступінь зацікавлення аудиторії певною інформацією. Саме від цього залежать увага і зусилля до когнітивної обробки інформації (Іванов 26).

Необхідною умовою будь-якої комунікативної взаємодії є процеси розуміння й інтерпретації отриманого адресатом вербального повідомлення. Складова частина успішної комунікації - правильне декодувананя адресатом отриманої інформації, розуміння когнітивного значення і сенсу, закладеного імпліцитно. Дослідники розуміють медіадискурс як архетип, що обмежує можливості соціального знання й поведінки. Він визначає конкретність, «точність» понять інших аспектів медіареальності, їхню інтерпретацію відповідно до досвіду мовця, пов'язаного з конкретним комунікативним і соціальним середовищем (Schneiderová 22).

Важливим аспектом когнітивного аналізу медійного дискурсу $є$ дослідження і характеристика різних видів знань і репрезентованої у структурах знань інформації, необхідної для здійснення дискурсивної взаємодії комунікантів. До аналізу дискурсу залучають різні види інформації, представлену як експліцитно, так і імпліцитно на свідомому і підсвідомому рівнях. У зв'язку із цим говорять про інформацію, повідомлювану навмисно, i інформацію, повідомлювану ненавмисно (Schiffrin): перший тип інформації вводиться в комунікативний процес мовцем / адресантом, який відображає потрібні змісти, надає їм комунікаційної форми й повідомляє їх відповідно до своїх інтенцій; інформація другого типу створюється реципієнтом / адресатом у процесі інтерпретації дискурсу і є результатом його інференцій, при цьому адресат / реципієнт може вивести змісти, відмінні від задуманих адресантом / мовцем (Цурикова 152).

Коли в тексті відображається подія, це передбачає наявність затексту (того, що за кадром) - фрагменту події, що описується в тексті. Журналіст, у свою чергу, описує затекст так, як уважає за потрібне. Завдяки асоціативності одиниць тексту, адресат може зрозуміти приховану інформацію, яка називається підтекстом. Основними характеристиками медіатексту є логічна закінченість висловлювань, прагматична установка та комунікативний намір (Яцимирська 65-66). Слід додати, що сприймання інформації кожним адресатом формується на основі індивідуальних етнокультурних знань, морально-духовних цінностей, суб'єктивних знань і уявлень про навколишній світ. Відповідно комунікант «може сприймати внутрішньотекстову інформацію повністю відповідно до задуму автора 
(акцептація), частково (трансформуючи деякі елементи «під себе») або зовсім її відкинути (негація)» (Адамка).

Із позиції когнітивної лінгвістики фразеологічні одиниці розглядають як засіб «кодування» й актуалізації концептів. На думку М. Алефіренко, універсальність і цінність фразем у когнітивному аспекті полягає в тому, що вони «характеризуються синергетичною взаємодією мовного, комунікативного, прагматичного, психічного й культурного факторів» (6). Крім того, ФО є «найбільше культурно маркованими образними одиницями будь-якої мови» (Алефиренко 5), що дозволяє говорити про національно-культурну специфіку фразеологізмів.

Фразеологізми $\epsilon$ засобом зберігання й організації знань, акумульованих у фразеологічній семантиці, про навколишній світ у свідомості суспільства. Аналіз внутрішньої форми фразеологічних одиниць сприяє більш глибокому розумінню особливостей взаємозв'язку мови й свідомості в контексті дослідження цілісного процесу пізнання світу. В. Телія підкреслює, що «система образів, закріплених у фразеологічному складі мови, слугує своєрідною 'нішею' для кумуляції світобачення й так чи інакше пов'язана з матеріальною, соціальною або духовною культурою мовної спільноти і через те може свідчити про її культурно-національний досвід і традиції» (Телия 215).

О.Яцкевич уважає, що в основі фразеологізму завжди є образ, «картинка», не важливо, чи зрозуміла, чи пов'язана зі значенням цілої одиниці, чи ні, але якщо розуміти значення слів-компонентів ФО, то образ можна собі уявити (33). Поняття внутрішньої форми є образом, що покладений в основу найменування. Виходячи з цього, можна припустити, що ще на стадії вільного словосполучення, яке згодом фразеологізувалося, стрижневе слово становило ядро образу, тобто було основою для формування внутрішньої форми. Саме у внутрішній формі фразеологізму утримується основна інформація, пов'язана з соціально-культурними, психологічними особливостями народу. Отже, аналіз ФО в медійному дискурсі в когнітивному аспекті дозволяє простежити особливості концептосфери як окремої людини, так і українського народу загалом.

Частотними в сучасному медіапросторі, за нашими спостереженнями, $\epsilon$ ФО, які містять вияв негативних оцінок мовців. Таке сприймання ситуацій, що відбуваються в суспільно-політичній сфері країни, відображається активним використанням узуальних і трансформованих ФО в медійному дискурсі: плести інтриги; копати яму; ніж у спину; підкладати свиню; водити за ніс; підводити під монастир. Вважаємо, що емоційний стан мовця відображає оцінка, «яка експліцитно вказує на позитивне або негативне ставлення до певної ситуації, проблеми, питання» (Князь 58).

У ФО плести інтриги асоціативний зв'язок з підступними діями заради своїх інтересів здійснюється через образ, викликаний стрижневим словом-компонентом інтриги. Наприклад: Бурбак закликав коаліцію 
припинити «плести інтриги» та об'єднатися заради поставлених цілей (112.ua, 17 лютого 2016) (далі після цитати буде подано покликання на іï джерело: видання та дату публікації матеріалу).

Образ ФО водити за ніс поєднується із зооморфним кодом культури, що зберігає зумовлені культурою стереотипні уявлення про характеристику або поведінку тварин. У ФО відображується метафоричне уподібнення поведінки тварини і людини. Авторська трансформація, зокрема розширення компонентного складу, зосереджує увагу на негативних діях щодо країни загалом, наприклад: «Годі водити Україну за ніс!» - Кравчук (Західна інформаційна корпорація, 11 жовтня 2019).

Сприймання неприємних ситуацій, дій, зроблених у соціальній сфері країни з негативним умислом, у свідомості комунікантів асоціюється з ФО підводити людей під монастир; ніж у спину; підкласти свиню. В основі образу фразеологізму підкласти свиню, як відомо, покладена ситуація релігійного характеру, коли могли підступно підкладати вірянам свинину, щоб влаштувати неприємність або пожартувати над кимось. Дієслівний компонент підклади у внутрішній формі ФО реалізує додаткові семи «потайки що-небудь робити», «з умислом що-небудь класти». Наприклад: Поки Кличко у відпустці, депутати Київради можуть «підкласти свиню» 3 Подільським мостом (depo.ua, 13 лютого 2020). Синонімічне значення реалізує ФО ніж у спину, наприклад: «Україна встромила Угорщині ножа в спину, внісши зміни до закону про освіту, який сильно порушує права угорської меншини», - заявив Сіярто, відзначивши, що Угорщина вважає закон ганебним (Європейська правда, 8 вересня 2017).

Когнітивні механізми свідомості мовців асоціюють образ складної ситуації з фразеологізмом підводити під монастир, у якому закодована інформація про серйозні життєві невдачі, неприємності, що змушують людей звертатися за духовною допомогою, а отже, йти в церкву, монастир. Наводимо ілюстрацію: "Якщо взялися за соцсферу, то треба працювати $i$ відповідати за результат, і не підводити людей "під монастир", підсумовує він (депутат Черкаської облради Вадим Гайович) (телеканал «ВІККА», 26 березня 2020).

Когнітивний аспект у дослідженні ФО передбачає не лише характеристику певної ситуації, а точніше врахування специфіки їі сприйняття, наявності необхідних знань, що сприяють цьому, інтенцій, емоційно-оцінного ставлення, зосередження уваги на певних елементах ситуації. Фіксуємо трансформовану ФО копати під Кабмін Гончарука (пор. узуальна одиниця копати яму - «підступно, таємно готувати комусь нещастя, неприємність») у складі заголовку статті: «Чвари олігархів: Навіщо Коломойський копає під Кабмін Гончарука?» (112.ua, 16 січня 2020). Розширення компонентного складу ФО за рахунок словакомпонента, що $\epsilon$ ключовим іменем (Гончарук), використано 3 прагматичною метою - реалізації тактики дискредитації опонента, зокрема підкреслення підступних дій олігарха до цієї особи. Урахування 
ситуації, раціональної та емоційної оцінки дійсності дає можливість виділити імпліцитну інформацію у значенні ФО.

Цікавим $\epsilon$ використання трансформованих ФО, до складу яких належать слова-компоненти, ключові імена. Вибір ключових імен, на думку Л. Цоневої, визначається комунікативним наміром автора. Як і в інших формах мовної гри, для осмислення ігрового фразеологізму й оцінки його експресивності адресатові необхідні не тільки лінгвістичні знання (про самий фразеологізм-прототип, його значення), але й знання про актуальну політичну ситуацію, про актуальних політичних суб'єктів, про конкретні події з їхньою участю тощо, котрі аналізуються в медіатексті (Цонева 156).

Мовна особистість упливає на формування світоглядних установок, ціннісних пріоритетів різних категорій суспільства. У медійних виданнях вона репрезентує образ носія мови і національно-культурних традицій, що відіграє певну соціально-культурну роль у суспільстві. Мовна особистість журналіста, його когнітивна здатність, особливості світосприйняття, професійний досвід створюють основу під час укладання публікацій у медійних видань. На думку дослідників, ключовою фігурою в медіатекстах $€$ наратор, тобто автор, який не просто укладає текст, а є суб'єктом всього текстового простору. Його присутність дозволяє представити різні види інформації: затекстову, фактологічну, концептуальну. Актуалізація діалогових відносин «автор - адресат» відбувається завдяки вибудовуванню складних прагматичних зв'язків із цільовою аудиторією (Овчарова 141-142).

Одним із важливих завдань медійних видань, крім об’єктивного викладу фактів, є інтерпретувальне відбиття реальності, яке, на думку Л. Гончарової, завжди було індивідуально-авторським або колективно-авторським (редакція) вибірковим конструктом, «утилітарно-прагматичною картиною світу» (117). У зв'язку із цим особливе значення має індивідуальноавторська репрезентація фактів різними лексико-фразеологічними засобами у медійних виданнях.

На думку Т.А. ван Дейка, незважаючи на соціальну зумовленість концептуального сприйняття ситуацій, когнітивні моделі є суб'єктивними (Дейк 82). Саме тому, з одного боку, способи відображення однієї новини, події можуть бути інтерпретовані різними мовними засобами, мати різну мету, а також свою специфіку порівняно зі стратегією висвітлення цієї ж інформації в аналогічному виданні. 3 іншого боку, для адекватного розуміння й сприймання повідомлюваної інформації необхідний збіг так званих когнітивних баз учасників комунікації, тобто наявність схожих знань і уявлень, характерних для членів українського суспільства.

Висновки та перспективи дослідження. Отже, у медійному дискурсі фразеологічні засоби мають особливий когнітивний i комунікативний потенціал. При цьому ФО виконують важливу прагматичну роль, оскільки саме вони формують структуру соціально-політичної, культурної 
концептуалізації й аргументації. Трансформування ФО реалізує їх прагматичний потенціал, що сприяє успішному впливу на адресата. Використання ФО в медійному дискурсі сприяє реалізації різних тактик: самопрезентації, дискредитації опонента тощо.

Проаналізовані фразеологізми в медійному дискурсі відображають сприймання українцями негативних ситуацій, що пов'язані з суспільнополітичною сферою в країні загалом. Це $\epsilon$ яскравим свідченням рис, притаманних українському менталітету, що виявляються, зокрема, у вмінні критично ставитися до негативних проявів дій, учинків певних людей.

Актуальним вважаємо подальше дослідження особливостей функціонування узуальних і трансформованих фразеологізмів української мови в медійному дискурсі в когнітивному й прагматичному аспектах.

\section{Список використаних джерел}

Західна інформаційна корпорація. URL: https://zik.ua

Європейська правда: інтернет-видання URL https://www.eurointegration.com.ua

Телеканал «112 Україна». URL https://ua.112.ua/

Телеканал «ВIККА». URL https://www.vikka.ua

depo.ua: суспільно-політичний портал. URL https://kyiv.depo.ua.

Zakhidna informatsiina korporatsiia. zik.ua

\section{Sources}

Yevropeiska pravda: internet-vydannia. www.eurointegration.com.ua

Telekanal «112 Ukraina». ua.112.ua/

Telekanal «VIKKA». www.vikka.ua

depo.ua: suspilno-politychnyi portal. https://kyiv.depo.ua.

\section{Список використаної літератури}

Адамка, Павол. «Лингвистическая рефлексия интенциональности словацкого медиадискурса». Медиалингвистика, №6 (1), 2019, с. 75-86. doi.org/10.21638/spbu22.2019.106

Алефиренко, Николай. Фразеология в свете современных лингвистических парадигм. Москва: Элпис, 2008.

Гончарова, Любовь. «Коммуникативные возможности рекламных текстов: праксиологический аспект». Медиалингвистика, вып. 4, 2015, с. 116-21.

Дарбанов, Буркутбай. «Некоторые понятия дискурса в моделях понимания текста». Актуальные проблемы гуманитарных и естественных наук, № 2, 2017, с.72-5.

Дейк, Тён ван. Язык. Познание. Коммуникация. Перевод с англ. Благовещенск, 2000.

Іванов, Валерій. Основні теорії масової комунікації $і$ журналістики, за редакцією В. В. Різуна. Київ: Центр Вільної Преси, 2010.

Овчарова, Галина. «Специфика коммуникативных продуктов в пространстве медиа». Теоретические и прикладные аспекты современной науки. Белгород, 2014, с. 140-2.

Князь, Тетяна. Емоційно-оцінні фразеологізми української мови в політичному дискурсі. Лінгвостилістичні студії, вип. 11, 2019, с. 54-64. doi.org/10.29038/2413-0923-2019-11-54-64

Красных, Виктория. Основы психолингвистики и теории коммуникации. Москва, 2001.

Кубрякова, Елена. «О реализации значения слова в дискурсе». Язык $u$ действительность. Москва, 2006, с. 367-71. 
Телия, Вероника. Русская фразеология. Семантический, прагматический $и$ лингвокультурологический аспекты. Москва, 1996.

Цонева, Лиляна. Имена и люди. Ключевые имена в медиадискурсе. Велико-Тырново, 2017.

Цурикова, Любовь. «Проблемы когнитивного анализа дискурса» Вестник Воронежского государственного университета. Серия 1, Гуманитарные науки, № 2, 2001, c.128-57.

Яцимірська, Марія, і Драган, Наталя. «Медіатекст як продукт журналістської творчості (психолінгвістичний аналіз логічного сприйняття та емоцій)». Вісник Львівського університету. Серія журналістика, вип. 30, 2007, с. 267-76.

Яцкевич, Ольга. «Система фразеологічної номінації концепту „людина” в українській мові». Лінгвістичні дослідження, вип. 14, 2004, с. 32-7.

Dijk, Teun Adrianus Van. “On Context”. Discourse Society, no.10, 1999, p. 291-2.

Cook, Guy. Discourse and literature. Oxford: Oxford Univ. Press, 1994.

Plett, Heinrich. Textwissenschaft und Textanalyse: Semiotik, Linguistik, Rhetorik. Heidelberg: Quelle und Meyer, 1975.

Shciffrin, Deborah. Approaches to discourse. Oxford, UK and Cambridge, MA: Biackwell, 1994.

Schneiderova, Sona. Analýza diskurzu a mediální text. Praha: Karolinium, 2015.

\section{References}

Adamka, Pavol. "Linguistic Reflection of the Slovak Media-Discourse Intentionality". Media Linguistics, №6 (1), 2019, pp. 75-86. doi.org/10.21638/spbu22.2019.106

Alefirenko, Nikolaj. Frazeologija v svete sovremennyh lingvisticheskih paradigm. Moskva: Jelpis, 2008.

Goncharova, Lubov. "Communicative Potential of Advertising Texts: Praxeological Aspects". Media Linguistics, iss. 4, 2015, pp. 116-21.

Darbanov, Burkutbaj. "Nekotorye ponjatija diskursa v modeljah ponimanija teksta". Actual problems of the humanities and natural sciences, № 2, 2017, pp. 72-5.

Dijk, Teun Adrianus Van. Jazyk. Poznanie. Kommunikacija. Blagoveshhensk, 2000.

Ivanov, Valerii. Osnovni teorii masovoi komunikatsii i zhurnalistyky, edited by V.V. Rizuna. Kyiv: Tsentr Vilnoi Presy, 2010.

Ovcharova, Galina. "Specifika kommunikativnyh produktov v prostranstve media". Teoreticheskie i prikladnye aspekty sovremennoj nauki. Belgorod, 2014, pp. 140-2.

Kniaz, Tetiana. "The Ukrainian Emotionally-Evaluative Phraseologisms in the Political Discourse". Linguostylistic Studies, iss. 11, 2019, pp. 54-64. doi.org/10.29038/24130923-2019-11-54-64

Krasnyh, Viktorija. Osnovy psiholingvistiki i teorii kommunikacii. Moskva, 2001.

Kubrjakova, Elena. “O realizacii znachenija slova v diskurse”. Jazyk i dejstvitel'nost'. Moskva, 2006, pp. 367-71.

Telija, Veronika. Russkaja frazeologija. Semanticheskij, pragmaticheskij $i$ lingvokul'turologicheskij aspekty. Moskva, 1996.

Coneva, Liljana. Imena i ljudi. Kljuchevye imena v mediadiskurse. Veliko-Tyrnovo, 2017.

Curikova, Ljubov'. "Problemy kognitivnogo analiza diskursa". Vestnik Voronezhskogo gosudarstvennogo universiteta. Serija 1, Gumanitarnye nauki, no. 2, 2001, pp. 128-57.

Yatsymirska, Mariia, and Drahan, Natalia. "Mediatekst yak produkt zhurnalistskoi tvorchosti (psykholinhvistychnyi analiz lohichnoho spryiniattia ta emotsii)". Visnyk of the Lviv University. Series Journalism, iss. 30, 2007, pp. 267-76.

Yatskevych, Olha. "Systema frazeolohichnoi nominatsii kontseptu "liudyna" v ukrainskii movi”. Lingvistichni doslidzhennja, iss. 14, 2004, pp. 32-7.

Dijk, Teun Adrianus Van. “On Context”. Discourse Society, no.10, 1999, p. 291-2.

Cook, Guy. Discourse and literature. Oxford: Oxford Univ. Press, 1994. 
Plett, Heinrich. Textwissenschaft und Textanalyse: Semiotik, Linguistik, Rhetorik. Heidelberg: Quelle und Meyer, 1975.

Shciffrin, Deborah. Approaches to discourse. Oxford, UK and Cambridge, MA: Biackwell, 1994. Schneiderova, Sona. Analýza diskurzu a mediální text. Praha: Karolinium, 2015.

Стаття надійшла до редколегії 27.09.2020 